DOI: $10.2478 / \mathrm{v} 10122-010-0014-\mathrm{x}$

\title{
ON TYPOLOGY OF POLISH AND FRENCH IMPERFECTIVE
}

\author{
MAGDALENA KAROLAK
}

\begin{abstract}
Magdalena Karolak. On Typology of Polish and French Imperfective. Lingua Posnaniensis, vol. LII (2)/2010. The Poznań Society for the Advancement of the Arts and Sciences. PL ISSN 00794740, ISBN 978-83-7654-078-8, pp. 67-77

The aim of this paper is to present a typology of Polish imperfective past tense forms in the factual use for the purpose of creating a set of guidelines for their translation into French language. Although descriptions of factual imperfective aspect is not new to linguistics, both Polish and international, equivalence of its forms in other languages pose problems to foreigners and native speakers alike. This is especially true in French, where Polish past imperfective forms could be expressed by a number of past tenses. In order to proceed with our task we are going to adopt a classification of Polish imperfective verbal forms based on the following criteria: general factual meaning or specific (concrete) factual meaning as a primary measure and imperfective or perfective intention of the imperfective form as a secondary measure. Such systematization of the phenomenon in Polish will allow us to formulate guidelines of equivalence with French past tenses.
\end{abstract}

Magdalena Karolak, New York Institute of Technology - Bahrain Campus

\section{INTRODUCTION}

Factual meaning of imperfective aspect can be defined as a particular type of verbal use that aims at informing whether the state of action described by the verb took place before the moment of speech. DAHL (1985: 75) stated that

In Slavic aspectology, one often talks of the so-called "general factual" or "simple denotative" use of the Imperfective aspect, where "there is no specific reference to the completeness of the event" and "the speaker is simply interested in expressing the bare fact that such and such an event did take place, without any further implications."

Factual use attracted attention of linguists since contrary to a narrow understanding of perfective and imperfective aspects as a binary opposition; Slavic imperfective could describe accomplished facts. Particular Slavic languages show a varying degree of range of this phenomenon with a larger extent in East Slavic languages.

Translation of Polish imperfective past tense forms requires no doubt assessment whether the imperfective form has a perfective or imperfective interpretation. This is however insufficient to determine the choice of French past tense to be used in translation. We suggest categorizing the imperfective forms according to criteria of general factuality and specific (concrete) factuality as a primary category and imperfective or perfective intentions of the imperfective form as a secondary category. 


\title{
2. GENERAL FACTUALITY AND SPECIFIC FACTUALITY
}

Defining general factuality and specific factuality is essential to our research. Specific meanings denote events that happened once in the past. General meanings are, in our opinion, synonymous with the concept of existential (experiential) perfect. They relate to single or repeated events characterized by the fact that "certain qualities or knowledge are attributable to the agent due to previous experience" (BYBEE et al. 1994: 62) as a result of the event(s). To clarify, we provide the following examples.

\section{Co jadłeś na obiad?}

What you HAVE-imp-2 sg for lunch?

Naprawiałem kiedyś mój komputer i wiem, jak to się robi.

I REPAIR-imp-1sg my computer and I know how to do this.

The first sentence is an example of specific meaning with one time occurrence event that does not seem to have any effect on the life experience of the subject. The second example provides us with a statement of gained experience new to the subject "I know how to do this." Making such distinctions is not always obvious. General meanings can co-occur with expressions such as kiedyś, kiedykolwiek (ever), nigdy (never) but usually their meaning has to be determined from the context. Expression sam widziałem below indicates the new perspective on war that the subject obtained thanks to personal experience.

Sam widziałem wojnę, to znaczy straszny amok ssaków, które mordują się wzajemnie aż do ostatecznego wyczerpania. (KoNwicki 1996)

I SEE-imp-1sg war myself, that means this terrible amok of mammals slaughtering each other till final exhaustion. (translation by the author)

General meanings might be associated with a repetition of the event. Although it is not the rule; as KAROLAK (2008: 44) noted "le parfait d'expérience fait abstraction du caractère unique ou répétitif des activités grâce auxquelles l'expérience a été acquise.” In the followig examples we observe that a specific or a general meaning will be assigned, respectively, depending on singular or plural of the object. A correlation between specific factual meanings in Polish and use of definite article in other languages has been suggested (FILIP 1993).

\author{
Czy doiłeś krowę? \\ You MILK-imp-2sg (the) cow? \\ Czy doiłeś krowy? \\ You MILK-imp-2sg cows?
}

\section{IMPERFECTIVE OR PERFECTIVE INTENTIONS OF THE IMPERFECTIVE FORM}

Our study will focus on the perfective intention of the imperfective form, since this particular use is factual. Imperfective intention on the other hand cannot describe events that occurred in the past but only those that at some point were in the process of happening. The peculiarity of factual use in Polish language is that in some cases, use of imperfective 
forms to describe accomplish facts is more popular among speakers than the use of their perfective counterparts. It is important to note however that not all imperfective verbs allow a perfective interpretation. ŚMIECH (1971) observed that in cases where the result is known or if we can judge from the situation that the result was achieved, imperfective forms can have a factual use. This very broad approach can be easily questioned. BogustawsKi (1981) on the other hand determined a detailed set of rules that must be met simultaneously:

- the meaning of the IMP which is actually used with reference to singular facts is WHOLLY included in the meaning of the PF;

- the presence, or for negated phrases, absence of the latter or, for inchoatives, earlier state of affiars indicated by the PF but not by the relevant IMPF is obvious;

- the earlier (or the later, in the case of inchoatives) state of affairs denoted by the IMPF is, from speaker's standpoint, essential in the given frame of reference; at the same time, the IMPF replaces a PF which is NOT taken to mark an earlier point of reference in a temporal sequence.

Bogusławski's approach enables to determine verbs that cannot be used in factual meanings. For the purpose of translation, we need however to proceed with a complex system of checks that includes our first and second criteria of study.

\section{METHODOLOGY}

We examined verbs contained in the electronic dictionary of Polish language with 100,000 words. We applied the general and specific factual criteria to verbs grouped by categories of Aktionsart established by VENDLER (1957) and completed by DowTY (1979). Our findings confirmed that verbs of states were incompatible with factuality. States are by definition characterized by a lack of starting point or end endpoint and do not yield results, thus they are unable to provide factual meanings. In other groups namely, achievements, accomplishments, activities and punctual verbs, we found imperfective forms in factual and general meanings. We need to discuss however the scope of factuality for each of the verbal groups in detail.

\subsection{PUNCTUAL VERBS}

Assessment of punctual verbs provides us with interesting findings. A number of punctual verbs such as kucać, błysnać, mrugnać, pękać, przestać, ciagnać, uśmiechać się, ściskać did not allow a factual use since the meaning of imperfective for was not fully contained in the perfective form (first condition of Bogusławski). A number of verbs allow only a specific factual use. These verbs that we consider a first category include: kichać, jęczeć, klaskać, kwiczeć, stękać, chrzakać, ryczeć, warczeć, chuchać, podskakiwać, machać. Even though imperfective form of a punctual verb denotes iterativity (kichać means kichnać more than once), factual use can relate to one-time occurrences as shown in the example below. The question is asked after the speaker heard one sneeze.

$$
\begin{aligned}
& \text { Czy to ty kichałeś? } \\
& \text { You SNEEZE-imp-2sg? }
\end{aligned}
$$


Other verbs might have, depending on situation, either a specific factual or a general factual meaning. These verbs of second category include: cofać, strzelać, dmuchać, krzyczeć, klepać, dopinać, zaczynać, kaszleć, klękać, dotykać, startować. We test them in the following manner.

(7a) Czy zaczynałeś od akustycznej? (specific)

You START-imp-2sg with acoustic guitar?

b) Czy zaczynałeś kiedyś coś, czego nigdy nie chciałeś skończyć? (general) You START-imp-2sg ever something that you would not want to finish?

(8a) Skoro miałeś 1,19 promila, to dlaczego chwytałeś za kierownicę? (specific) Since you had 1,19 BAC why you GRAB-imp-2sg the steering wheel?

b) Chwytałeś kiedyś dłoń we mgle, by po chwili zorientować się, że tam jej nie było? (general)

You CATCH-imp-2sg ever a hand in the fog only to find out that it was not there?

The difference between the first category and the second one is purely semantic. It is grammatically correct to ask Czy kiedykolwiek kichateś? (general factuality) but it sounds artificial. We observe also that classification of some verbs is based on a purely customary character of their use. Verb zaczynać contrary to its antonym przestawać allows factual meanings as illustrated above. Third category that would include verbs with exclusively factual general use has no examples among punctual verbs.

\subsection{ACCOMPLISHMENTS}

Accomplishments are telic verbs characterized by an end point resulting in some sort of a state. After its achievement, the event can no longer be continued. From the point of view of our research we have to distinguish between two types of accomplishments. The first one includes verbs which results are natural and inevitable. They allow a factual use. Verbs which results are not necessarily achieved do not offer a factual use.

Table 1. Division of accomplishments according to expected result

\begin{tabular}{|l|l|}
\hline \multicolumn{1}{|c|}{ Accomplishments (result is achieved ) } & \multicolumn{1}{|c|}{ Accomplishments (no necessary result) } \\
\hline $\begin{array}{l}\text { budować, pisać, projektować, czytać, badać, } \\
\text { meblować, podłączać, dekorować, obliczać, }\end{array}$ & $\begin{array}{l}\text { topić, nakłaniać, bronić, włamywać się, przeko- } \\
\text { nywać, zachęcać, odwodzić, uczyć, targować, } \\
\text { kończyć, lakierować, oceniać, nagrywać, } \\
\text { kopiować, naprawiać, zamawiać, umawiać } \\
\text { się }\end{array}$ \\
\hline
\end{tabular}

To clarify this important distinction we observe the differences in the examples below.

Nauczyciel języka polskiego ocenial mi tę pracę.

Polish language teacher GRADE-imp-3sg this paper.

Topil się w morzu, ale został uratowany.

He DROWN-imp-3sg in the sea but he was saved. 
Replacing imperfective form topit sie with its perfective counterpart is semantically wrong (*Topił się w morzu, ale został uratowany.). Thus the form topit się has a strictly imperfective reading.

\subsection{ACHIEVEMENTS}

Achievements are characterized by a sudden end point within which the result, a passage from one state to another, is achieved. "Achievements occur at a single time [and] involve unique and definite time instants" (VENDLER 1957). They differ from punctual verbs precisely by the fact that they result is a change of state. On the other hand, unlike accomplishments, achievements can be preceded by a telic action but the essence of their meaning lies in the result itself. Not all achievements allow a factual use; these are, between the others, verbs such as rozbijać, nadejść, udać się.

We categorized verbs that have a factual use according to criteria of specific or general factuality. We noted among verbs that have only a specific factual use the following: budzić się, powiadamiać, decydować, zapalać, meldować, poznawać. Secondly, verbs that dependent on the context have a specific or general factual meanings are: dawać, dzwonić, cumować, głosować, oddawać, kłamać, brać, obiecywać, mówić, naciskać, widzieć, przebijać, chorować, kraść. We found also a case of a verb allowing solely a factual meaning: zabijać. The latter example is worth exploring.

$$
\begin{aligned}
& \text { Zabijałeś już kiedyś ludzi za pieniądze? } \\
& \text { You KILL-imp-2sg ever people for money? } \\
& \text { Proszę opowiedzieć, jak pan zabił milicjanta. } \\
& \text { - Żadnego milicjanta nie zabijałem. (general factual) } \\
& \text { Tell us please how did you kill the policeman. } \\
& \text { I KILL-imp-1sg no policeman. }
\end{aligned}
$$

The second example includes a negation. WŁODARCZYK (1997: 156) noted that the difference between a negated perfective form and imperfective on lies precisely in the distinction between specific and factual menings: "Si le procès nié est en meme temps considéré comme ayant une valeur générale, on emploiera l'imperfectif ; si l'on veut au contraire faire porter la négation sur une occurrence particulière du procès, on choisira le perfectif." The negation means that there has never been such a case when the subject killed a policeman.

\subsection{ACTIVITIES}

Activities are atelic and their duration spreads in time. Since they do not have a natural end point, factual meaning will denote a simple interruption of the activity. It is important to observe that some verbs of activities are in Polish known as imperfectiva tantum and do not form aspectual pairs. Verbs that allow only a specific factual meaning include śmiać się, jeździć, grać, torturować, while those that could have specific or general meanings depending on the context, are kapać, czekać, palić, prowadzić, leżé, lecieć, czytać. We found examples of exclusively general factual meanings in verbs such as podróżować and siedzieć. 


\section{TRANSLATING FACTUAL MEANINGS TO FRENCH}

The problem of translation of factual meanings is a complicated task since this phenomenon is widespread especially in Slavic languages. In French language we observe a limited use of imparfait pittoresque, where an imperfective form can denote a perfective meaning. Its use is however restricted to literary texts. Furthermore, aspect in French, unlike in Polish, does not operate through aspectual pairing where verbal lexemes would be the only aspectual markers. French aspect is a result of combination of the verbal lexeme and the value of grammatical morpheme of each tense (KAROLAK 2005). In addition to that French language possesses a complex tense system. Five past French tenses can translate Polish past tense, the only tense in use in modern Polish language. The factual meanings of imperfective forms in Polish is translated essentially by passé compose and passé simple. Imparfait on the other hand might be accepted in some cases. Passé antérieur and plus-que-parfait are linked to the issue of temporal chronology of events (la concordance des temps) and we will omit them in this article.

\subsection{SPECIFIC AND GENERAL FACTUAL MEANINGS - IMPACT ON TRANSLATION}

General factual meanings, which we defined as synonymous with experiential perfect, denote events that have a result visible in the present since they are part of life experience of the subject. In French language passé composé is the only tense that can express the link of past with present. MARTIN (1971: 109) observed that "[le passé composé est reservé] à l'expression d'événements récents, le lien avec le moment présent le prédisposant à cet emploi." It is the most important difference between passé composé and passé simple. The choice between the two tenses depends on the point of view on the event. "Un événement passé rapporté au passé simple est un fait entièrement révolu et sans lien exprimé [...] avec la pensée et l'expérience actuelles de celui qui parle. Quand un tel lien est vu dans la perspective actuelle de celui qui le rapporte, la langue (écrite) a recours au passé composé." (ImBS 1968: 81).

\subsection{TRANSLATING GENERAL FACTUAL MEANINGS}

Due to the characteristic of passé composé mentioned above, this tense will be used to translate all general factual meanings as shown in the examples below.

(13a) - Wyście kiedy robili przy betonach? (SzCZYPIORSKI 1986)

You WORK-imp-1sg ever with concrete?

b) - Est-ce que vous avez déjà travaillé dans le béton?

c) * Est-ce que vous travaillâtes déjà dans le béton?

(14a) Andrzej był w Stanach i widzial Statuę Wolności.

Andrew BE-imp-3sg in the USA and SEE-imp-3sg the Statue of Liberty.

b) André est allé aux Etats-Unis et il a vu la Statue de Liberté.

c) André fut aux Etats-Unis et il vit la Statue de Liberté. 
Although sentence 14c is acceptable in French, the use of passé simple cannot convey the meaning of existential perfect but only a simple series of successive events.

\subsection{TRANSLATING SPECIFIC FACTUALITY WITH PASSÉ COMPOSÉ}

All events with specific factual meanings that occurred in the past and which results are experienced (observed) in the present will be translated with passé composé. In the example below, mother asks the question after she observed a strange behavior of her son.

- Piłeś alkohol Wiciu? (Konwicki 1976)

You DRINK-imp-2sg alcohol?

b) - Tu as bu de l'alcohol?

The effects of the alcohol abuse are observed in the present thus we require the use of passé composé. Similarly below, the subject is stygmatized by the way he looks. Instead of being considered a member of victorius race, people around him see him as a disabled person.

(16a) - Pan już bardzo mi pomógł. Jako Niemiec...

- Najpierw jestem garbusem. (...) Nie musimy mówić o narodowości. Wszyscy widzieli mój garb. (SzCZYPIORSKI 1990)

Everybody SEE-imp-3sg my hunchback.

b) - Vous m'avez déjà beaucoup aidé. En tant qu'Allemand...

- Je suis d'abord un bossu. Nous n'avons pas besoin de parler de nationalité.

De toute ma vie, personne n'a fait attention à ma nationalité. Mais tout le monde a vu ma bosse.

\subsection{TRANSLATING SPECIFIC FACTUALITY WITH PASSÉ COMPOSÉ OR PASSÉ SIMPLE}

Other types of specific factual meanings can be translated either with passé composé or passé simple. A general characteristic of both tenses will be necessary to determine the choice for translation. Passé simple is a literary tense, which forms survive in writing but are no longer used in speech. Gosselin (1996: 197) characterizes a typical use of passé simple as "autonome, ponctuel, inchoatif, situant le procès (au moins son début) dans le passé non immédiat, et marquant la succession des procès (ou au moins de leurs bornes initiales)." The following example provides an illustration.

(17a) Przez długie lata był moim prawdziwym bożyszczem. (KRALL 1992)

During many years he BE-imp-3sg my idol.

b) Durant des années, il fut mon idole.

The use of passé simple removes any link with present moment. The subject contemplates his youth from a distant perspective. At the present moment he can understand his past admiration for his idol. The continuation of the text explains that the subject's feelings ended in the past: "Wiesz - ja sobie w ogóle przedtem nie wyobrażałem, że on się może czegokolwiek bać. A on, mój idol, uciekał." The change of il fut mon idole for il a été mon 
idole is grammatically correct. Translator chose passé simple since use of passé composé changes the underlying meaning of the statement. Passé composé will denote status of an idol as a trait important enough to characterize the person in this period of time: "le procès est consideré comme suffisamment important pour caractériser un individu."

\section{PARTICULAR PROBLEMS FOR TRANSLATION}

Our observations stem from division factuality into specific and general meanings. We need however to pinpoint a more detailed overview of problems encountered during the process of translation.

\subsection{PERFECTIVE OR IMPERFECTIVE INTENTION}

Determining whether Polish imperfective form has an imperfective or perfective intention is an especially sensitive issue in case of verbs of accomplishments. The following series of translations offer an overview of French past tenses.

Kto budowal Auschwitz?

b) Qui a construit Auschwitz?

c) Qui construsit Auschwitz?

Auschwitz is a historical monument thus Polish imperfective form has definitely a perfective intention. The use of passé simple is grammatically correct in $18 \mathrm{c}$ however in a dialogue it would be considered a regional or a pedantic style (IMBS 1968: 87).

b) Un jour, j'ai cracké le compte gadu-gadu d'une amie. La fille est sympa mais pas très intelligente et après quelques essais, $\mathrm{j}$ 'ai cassé son mot de passe.

c) Un jour, je crackais le compte gadu-gadu d'une amie. La fille est sympa mais pas très intelligente et après quelques essais, $\mathrm{j}$ 'ai cassé son mot de passe.

Examples above illustrate a possibility of Imparfait use in the perfective intention. Similarly to Polish language, since the result is known, Imparfait can be use to stress the lenght and duration of an event. Passé simple was omitted since as a literary tense, it would not be appropriate combined with anglicism (cracker).

(20a) Ktoś się włamywal do zakrystii.

b) Quelqu'un a essayé d'entrer par effraction dans la sachrystie.

c) * Quelqu'un est entré / entra par effraction dans la sachrystie.

Example 20a offers a different situation, since the verb wtamywat się has an imperfective interpretation. Thus perfective tenses such as passé simple and passé composé are excluded. We chose to use the expression essayer de (to try to). This is however not the only solution. Other examples of imperfective intention can be found below. 
(21a) Pierwszy z zatrzymanych próbował się w celi podpalić, ale w ostatnim momencie powstrzymał go wartownik. Drugi wieszał się na kracie celi. Znaleziono go nieprzytomnego, ale żywego.

b) Le premier détenu a essayé de s'immoler par le feu dans sa cellule, mais a été stoppé juste à temps par un surveillant. Le second s'est pendu aux barreaux de sa cellule. Il a été retrouvé inanimé, mais vivant.

(22a) Coś tu budowali, ale potem zarzucili budowę.

b) Ils ont construit ici quelque chose, mais plus tard ils ont abandonné la construction.

Although Polish verbs wieszat się and budowali have an imperfective meaning, passé composé, a tense with perfect interpretation, was used in translation. The result, or to be precise lack of it, is known to the reader thanks to the context of the sentence (unlike in sentence 20 where no further context is provided). Passé simple, on the contrary, cannot translate results visible in the present moment.

\subsection{PROCESSUALITY}

Imperfective intention in Polish language is associated on certain occasions with duration of the event. While using French perfective tenses we might encounter a difficulty in expressing its processuality. Passé composé emphasizes the end point and the resultativity of the event and cannot translate processuality unless accompanied by adverbials of time (ImBs 1968: 205). For instance, it is improper to translate imperfective form czytatem with passé composé as $j$ 'ai $l u$, since the French form would have a perfective intention synonymous with przeczytałem. Consequently, example $22 \mathrm{~b}$ does not translate a difference between Polish forms budowali and zbudowali. While in Polish language the stress is put on the lack of result, passé composé emphasizes resultativity. This can be avoided when passé composé is combined with adverbial of time as illustrated below.

b) Ils ont construit ici quelque chose pendant quelques années, mais ils ont abandonné la construction.

Passé simple can be also combined with adverbials of time and express processuality. However in that situation "un circonstantiel de durée ou une quantification sur le SN objet imposent la prise en compte de la totalité de son déroulement" (GossELIN 1997: 198). That is why, example 23a cannot be translated with passé simple. Passé simple can express only the perfective form zbudowali (Ils construirent ici quelque chose pendant quelques années). We note that adverbial of time pendant quelques années maintains the processual reading.

\subsection{TWO-WAY ACTION VERBS}

The essence of meaning of two-way action verbs consists in an action that leads to a result. This result is however annulled by a subsequent action of an opposite effect (DAHL 
1985: 149). In Polish language this use is confined to a small group of imperfective verbs. Their subtle underlying meaning is difficult to translate.

(24a) Otworzyleś okno? You OPEN-perf-2sg the window?

b) Otwieraleś okno? (the window is closed at the moment of speech) You OPEN-imp-2sg the window?

In example $24 \mathrm{a}$ the use of a perfective form points on the result currently observed, i.e. is the window open right now. In $24 \mathrm{~b}$, the speaker asks about whether the action itself took place or not. At the moment of speech the window is closed but there might be some indication of previous opening such as, the room is cold. Translation of both sentences to French would be the same Est-ce que tu as ouvert la fenêtre? although it does not convey the two-way action verb meaning of $24 \mathrm{~b}$. We cite a similar examples below.

- Kto tu przychodzil?

- Staruszek, który kiedyś pracował w tym domu. Życzył nam szczęścia i błogosławił. (Konwicki 1976)

b) - Qui est-ce qui est venu ici?

- Un petit vieux qui travaillait autrefois dans cette maison. Il tenait à nous présenter ses voeux de bonheur et à nous donner sa bénédiction.

(26a) Pożyczałem od niego pieniądze.

b) Il m'a prêté de l'argent.

\section{CONCLUSION}

The aim of this paper was to assess the issue of factual verbs in Polish language and their equivalence in French. We have been able to establish guidelines for translation of general factual meanings as well as several pointers for translation of specific factual meanings. Our research was centered solely on the issue of factuality thus our goal was limited in scope and other phenomena that affect verb translation were purposely not included.

\section{REFERENCES}

BogusŁawsKi Andrzej. 1981. “On Describing Accomplished Facts with Imperfective Verbs.” In: JACOBSEN, KRAG 1981: 34-40.

Bybee Joan L., Perkins Revere, Pagliuca William. 1994. The Evolution of Grammar: Tense, Aspect and Modality in the Language of the World. Chicago: University of Chicago Press.

DAHL Osten. 1985. Tense and Aspect Systems. Oxford: Basil Blackwell Ltd.

Dowty David R. 1979. Word Meaning and Montague Grammar. Berlin: Springer.

FILIP Hana. 1993. Aspect, Situation Types and Nominal Reference. Doctoral Dissertation, University of California, Berkeley.

Gosselin Laurent. 1996. Sémantique de la temporalité en français. Louvain-la-Neuve: Editions Duculot. ImBs Paul. 1968. L'emploi des temps verbaux en français moderne. Paris: C. Klincksieck. 
Jacobsen Per, Krag Helen et al. (ed.). 1981. The Slavic Verb. An Anthology Presented to Christian Sørensen. Copenhagen: Rosenkilde.

KarolaK Stanisław. 2005. “Trois langues- trois visions du temps impliqué?” Neophilologica 17.

KarolaK Stanisław. 2008. "L’aspect dans une langue: le français.” Studia Kognitywne 8.

MARTIN Robert. 1971. Temps et aspect. Paris: Editions Klincksieck.

ŚMIECH Witold. 1971. Funkcje aspektów czasownikowych we wspótczesnym języku ogólnopolskim. Wrocław: Zakład Narodowy im. Ossolińskich.

Vendler Zeno. 1957. "Verbs and Times." The Philosophical Review 66(2), 143-160.

WeodarcZYK Hélène. 1997. L'aspect verbal dans le contexte en polonais et en russe. Paris: Institut d'Etudes Slaves.

\section{SOURCE OF EXAMPLES}

Konwicki Tadeusz. 1996. Mała Apokalipsa. Warsaw: Niezależna Oficyna Wydawnicza.

Konwicki Tadeusz. 1979. La petite Apocalipse. Paris: Éditions Robert Laffont.

Konwicki Tadeusz. 1976. Kronika wypadków miłosnych. Warsaw: Czytelnik.

Konwicki Tadeusz. 1987. Chronique des événements amoureux. Saint-Étienne: Publications Orientalistes de France.

Krall Hanna. 1992. Zdązyć przed Panem Bogiem. Warsaw: Wydawnictwo Gamma.

Krall Hanna. 2005. Prendre le bon Dieu de vitesse. Paris: Gallimard.

SzCZYPIORSKi Andrzej. 1990. Amerykańska whisky. Poznań: Kantor Wydawniczy SAWW.

SzCZYPIORSKi Andrzej. 1995. Whisky américain. Paris: Éditions de Fallois.

SzczYPIORSKi Andrzej. 1986. Początek. Poznań: Kantor Wydawniczy SAWW.

Szczypiorski Andrzej. 2004. La jolie Madame Seidenman. Éd. Liana Levi. 